\title{
DENDROCHRONOLOGICAL AND RADIOCARBON DATING OF SUBFOSSIL WOOD FROM THE MORAVA RIVER BASIN
}

\author{
TOMÁŠ KOLÁŘ and MICHAL RYBNÍČEK \\ Mendel University in Brno, Faculty of Forestry and Wood Technology, Zemédělská 3, 61300 Brno, Czech Republic
}

Received 7 July 2010

Accepted 5 January 2011

\begin{abstract}
The paper deals with dendrochronological and radiocarbon dating of subfossil trunks found in the basin of the Morava River. The research into subfossil trunks had been conducted in the Czech Republic in the past but the research stopped in 2001. 160 records of measurements of subfossil, predominantly oak trunk samples, are preserved from that time. Three years ago the research was reopened and again the most trunks were found in the basin of the Morava River. 92 samples of oak trunks and 7 samples of other tree species (poplar, elm, maple, beech) were taken from selected sites. The samples were processed in compliance with the standard dendrochronological methodology. To date the samples, Czech, Austrian, Polish and German standard chronologies were used. In cases when the dendrochronological dating was unsuccessful, the samples were sent for radiocarbon dating. In total, 35 samples were dated, mainly by the radiocarbon method. Subfossil trunks from gravel pit Tovačov were dated and classified into 4 different periods, the oldest being from 2780-2190 BC. In Osek nad Bečvou, the samples were taken from two sites. Whereas from the 4 trunks taken in the river channel each was from a different period, the trunks from the gravel pit come from 981-1015 AD. The trunks found in the Morava River basin near Strážnice were dated to the $10^{\text {th }}-15^{\text {th }}$ century. In the future, we expect to extend the amount of the acquired samples with the aim to create a link to the existing standard chronology or to create a long floating average tree-ring curve.
\end{abstract}

Keywords: dendrochronology, subfossil wood, oak, radiocarbon dating, the Morava River.

\section{INTRODUCTION}

Oak forests in Central Europe started to appear on river banks about 10,000 years ago, i.e. at the end of the Ice Age and the beginning of the Holocene (Becker, 1982; Leuschner et al., 1986). Trunks of dead trees were deposited and preserved in various sediments. There are several theories concerning the mechanism of trunk deposition and preservation. The most frequently cited theory talks about bank erosion in meanders or river erosion during large floods (Kalicki and Krąpiec, 1995; Máčka and Krejčí, 2009). The fallen trees then soaked up water

Corresponding author: T. Koláŕ

e-mail:koldatom@gmail.com and settled in deposited layers of channel alluvium under the water surface (Kalicki and Krąpiec, 1995; Florek, 1978; Kalicki and Krąpiec, 1991). The trunks were gradually hidden beneath the accretion on the slip-off slope during the channel migration (Kalicki and Krapiec, 1995). The slip-off slope is the relatively gentle slope at the inner edge of a meander. In this position they were well protected against disintegration by microorganisms, especially fungi and bacteria (Krapiec, 1996). These conditions allowed for their deposition for over 10,000 years (Becker, 1982). Today, these trunks are referred to as subfossil (Krąpiec, 1996; Kalicki and Krąpiec, 1995). Subfossil wood is unfossilized wood which has been deposited in rivers, swamps or moraine sediments for 
hundreds or thousands of years (Kaennel and Schweingruber; 1995). In former literature, subfossil oak trunks are referred to as "black oak" because of their colour (Kalicki and Krapiec, 1995). The change of the wood shade into black is caused by ferric components dissolved in water reacting with tannins present in oak. The intensity of the shade is primarily determined by the time for which the wood has been deposited and the nature of the sediment. Besides the changes of the shade, there are also changes in physical and mechanical properties (Govorčin and Sinković, 1995). Oak is the most frequent species existing in the subfossil form, but to a smaller extent there are also pine, elm, maple, poplar, beech, ash and alder (Dvorská and Vít, 2002).

Currently, subfossil trunks are often found in Holocene alluvia, in gravel pits during alluvial sand and gravel extraction (Krąpiec, 1996; Kalicki and Krąpiec, 1995). In the area of the Czech Republic these trunks are most often found in unregulated reaches of big rivers, especially the Morava, the Vltava and the Labe Rivers, and in gravel pits that are located in the basins of these three rivers.

The longevity of oaks growing at river banks during the Holocene was relatively short $-95 \%$ of the trees only contain 150-400 tree rings. This fact is put in relation with the frequency of the above mentioned floods (Becker, 1993).

Subfossil wood is a suitable material for the creation or extension of standard oak chronologies (Pilcher et al., 1984; Becker, 1993). In Poland the created standard chronology reaches from the current days till $474 \mathrm{BC}$ and 1795-612 BC (Krapiec, 1996, 2001), in Ireland till 5289 BC (Baillie, 1995) and in central Germany till 6255 BC (Leuschner, 1992). The longest standard chronology in the world was created in German Hohenheim and it reaches the year of 8480 BC (Becker, 1993, Spurk et al., 1998). To create the standard chronology, it is necessary to collect and date a large amount of trunks. The research into subfossil trunks in the Czech Republic was conducted until the end of 2001. The main objective besides the oak standard chronology was to use tree-ring analyses to obtain other paleoecological data. The first and a very important step within the project was the creation of a databank of possible deposits of subfossil trunks and the selection of sites suitable for further research. These sites were then consistently explored and the found trunks were sampled. When the trunks were found in the original location, the geological examination of the profile was carried out. The obtained samples were processed by means of dendrochronology and floating standard chronologies for each site were created. These were then compared with south German standard chronology, or with the standard chronology for southern Poland. The samples which could not be dated by dendrochronology were dated by radiocarbon method. The results are presented in Table 1 (Poláček et al., 2005).

Table 1. Summary of results of subfossil trunks research before 2001 (Poláček et al., 2005).

\begin{tabular}{|c|c|c|c|c|c|c|c|}
\hline Site & $\begin{array}{l}\text { Number of } \\
\text { samples }\end{array}$ & $\begin{array}{l}\text { Tree } \\
\text { species }\end{array}$ & $\begin{array}{c}\text { Number of dated } \\
\text { samples }\end{array}$ & $\begin{array}{l}{ }^{14} \mathrm{C} \text { age } \\
\text { (yr BP) }\end{array}$ & $\begin{array}{c}\text { Cal. age range } \\
95.4 \% \text { conf. } \\
\text { intervals } \\
\text { (yr AD/BC) }\end{array}$ & Final year & $\begin{array}{l}\text { Dendrochronological } \\
\text { dating }\end{array}$ \\
\hline \multirow{5}{*}{ Mohelnice } & & \multirow{3}{*}{ oak } & 1 & $1580 \pm 45$ & $390-600$ AD & 550 & after 550 \\
\hline & 6 & & 2 & $1380 \pm 45$ & $560-780 \mathrm{AD}$ & 564 & after 564 \\
\hline & & & 2 & $6170 \pm 50$ & $5310-4950 \mathrm{BC}$ & - & - \\
\hline & 3 & ash & - & - & - & - & - \\
\hline & 1 & alder & - & - & - & - & - \\
\hline Horka nad Moravou & 1 & oak & 1 & $2145 \pm 111$ & - & - & - \\
\hline Troubky & 1 & oak & - & - & - & - & - \\
\hline Kroměříž & 15 & oak & - & lost & - & - & - \\
\hline Hulín & 27 & oak & 12 & $3856 \pm 147$ & $2900-1850 \mathrm{BC}$ & $1668 \mathrm{BC}$ & after $1668 \mathrm{BC}$ \\
\hline \multirow{5}{*}{ Strážnice } & \multirow{5}{*}{70} & \multirow{5}{*}{ oak } & 22 & - & - & 1658 & after 1658 \\
\hline & & & 1 & $1000 \pm 40$ & $970-1160$ AD & - & - \\
\hline & & & 1 & $674 \pm 123$ & $1030-1460 \mathrm{AD}$ & - & - \\
\hline & & & 1 & $430 \pm 30$ & $1420-1620 \mathrm{AD}$ & - & - \\
\hline & & & 1 & $210 \pm 40$ & $1630-1960 \mathrm{AD}$ & - & - \\
\hline \multirow{2}{*}{ Hodonín } & 18 & oak & - & - & - & - & - \\
\hline & 1 & beech & - & - & - & - & - \\
\hline Mikulčice & 5 & oak & - & - & - & - & - \\
\hline Břeclav - Pohansko & 1 & oak & - & - & - & - & - \\
\hline Hustopeče nad Bečvou & 11 & oak & - & - & - & - & - \\
\hline
\end{tabular}

Note: Radiocarbon dating conducted in Gliwice Radiocarbon Laboratory 


\section{MATERIAL AND METHODS}

For the purposes of research, samples from subfossil trunks were taken from selected sites (Fig. 1). The first site is gravel pit in Tovačov, $12 \mathrm{~km}$ to the west of Přerov (GPS - 49 $24.264^{\prime} \mathrm{N}, 17^{\circ} 17.469^{\prime} \mathrm{E} ; 200 \mathrm{~m}$ asl). The other two sites - a reach of the Bečva River near Osek nad Bečvou (GPS - 49 $29.837^{\prime} \mathrm{N}, 17^{\circ} 31.271^{\prime} \mathrm{E} ; 218 \mathrm{~m}$ asl) and the gravel pit in Osek nad Bečvou (GPS $49^{\circ} 29.459^{\prime} \mathrm{N}, 17^{\circ} 31.531^{\prime} \mathrm{E}$; $218 \mathrm{~m}$ asl) - are also located in the Prrerov district. The last site is a reach of the Morava River near Strážnice (GPS - 48 55.530' N, $17^{\circ} 17.120^{\prime} \mathrm{E} ; 176 \mathrm{~m}$ asl) in the district of Hodonín.

Using a chain saw we took discs $5 \mathrm{~cm}$ thick. The discs better show possible defects in the tree growth (doubled or missing tree rings, wood knots, waving rings, etc.). Incorrect recognition of a growth defect may affect the accuracy of measurements (Rybníček, 2004). Before the measurement itself it was necessary to work the surface with a razor blade or rub it so that the boundaries of the tree rings were well visible.

To process the samples the PAST 4 application was used. We measured each sample in two mutually perpendicular directions. Measuring was conducted on a specialized measuring table with an accuracy of $0.01 \mathrm{~mm}$. The first step after measuring was the comparison of individual ring curves (Rybníček et al., 2007). As each sample was measured in two mutually perpendicular directions, one curve was created for a sample out of these two. The well synchronizable curves were then used to create the average tree-ring curve, which highlighted the common minima and maxima and at the same time suppressed all the other oscillations caused by other influences (Cook and Kairiukstis, 1990). The average tree-ring curve was then compared with the standard chronologies for that particular species. The samples of subfossil oak trunks were compared with Czech, German, Austrian and Polish standard chronologies. The degree of resemblance among the curves was evaluated by means of the correlation coefficients and the parallelism coefficient (Gleichläufigkeit). These calculations facilitate the optical comparison of both curves, which is crucial for the final dating (Rybníček et al., 2010).

The samples which could not be dated by the available standard chronologies were dated by a radiocarbon method. For radiocarbon dating it is necessary to use a sample with the minimum weight of $20-50 \mathrm{~g}$ (http://www.carbon14.pl).

\section{RESULTS}

During the past 2 years, 99 samples of subfossil trunks were taken from the selected sites in the basin of the Morava River and gravel pits which are located nearby. The proportions of particular tree species are shown in Fig. 2. There is over $90 \%$ of oak, where usually only

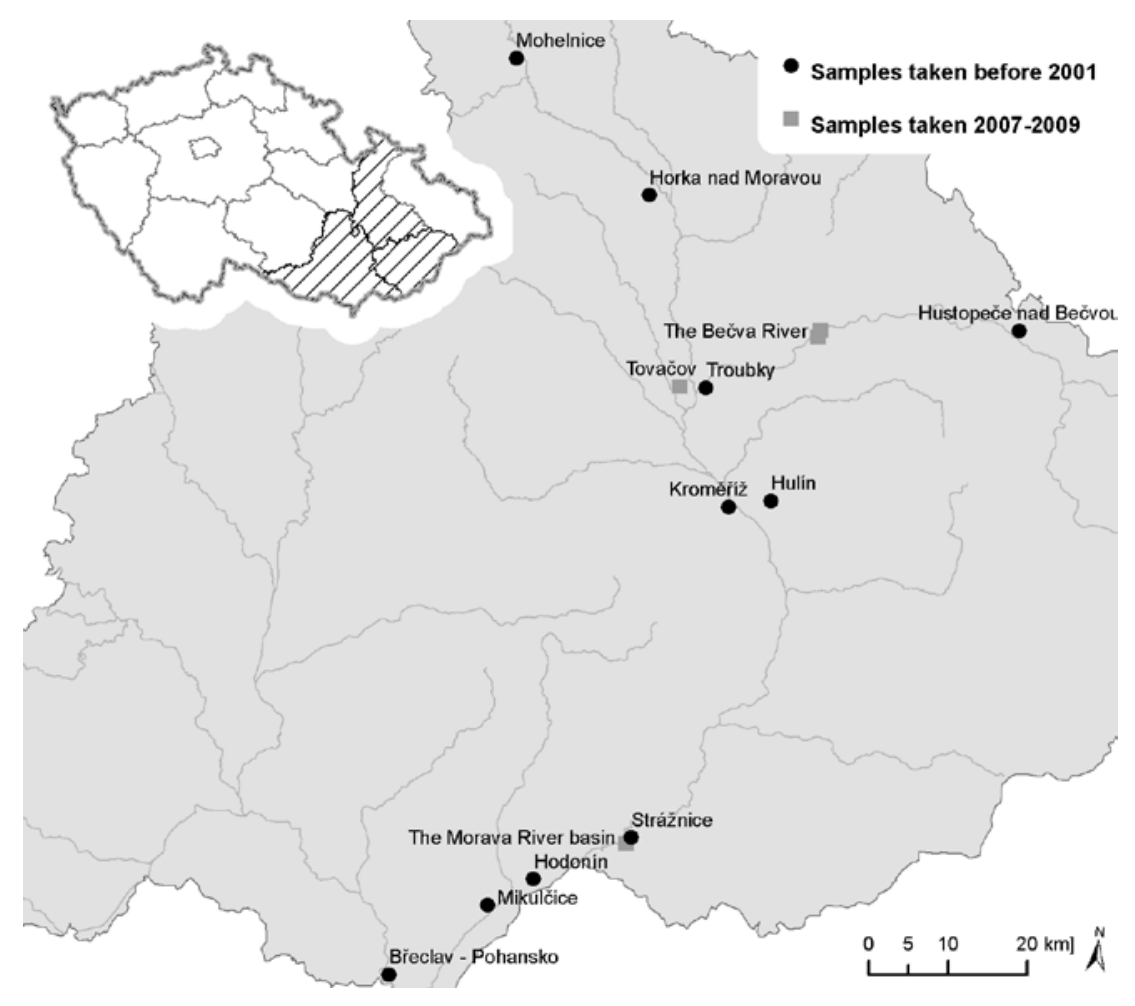

Fig. 1. Map showing site locations 
the heartwood has been retained without sapwood or with only a few sapwood rings.

\section{Tovačov}

Table 2 shows the results of the dating of samples taken in gravel pit Tovačov. In total, 33 samples were acquired here. All of them were dated by the radiocarbon method. The samples could not be dated by dendrochronological methods as the living trees had been attacked by cockchafer (Melolontha, Linnaeus).

\section{The Bečva River}

In the Bečva River basin (the main tributary of the Morava River) samples were taken from two sites - river basin near Osek nad Bečvou and in 2009 in a newly opened gravel pit in the immediate vicinity of the stream. In total, 13 samples were taken from the river basin, out

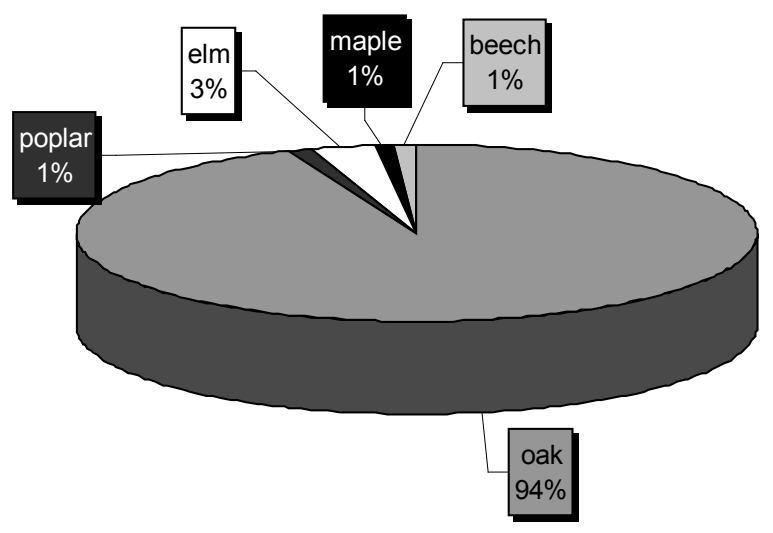

Fig. 2. The proportion of particular tree species in the existing samples of which 9 samples were oak wood and then there was maple, poplar, elm and beech, one sample each. None of the samples could be dated by dendrochronological methods, due to a small number of tree rings. Therefore, the chosen samples were sent for radiocarbon dating (Table 3). 37 oak samples were taken from the gravel pit. Four of them were dated dendrochronologically using the south German oak standard chronology (Table 4).

\section{The Morava River basin}

16 samples in total were taken in the south of Moravia near Strážnice (the Hodonín district) during the past two years. Until now, 14 of them were dated; all of them were dated by the radiocarbon method (Table 5) and 10 by the dendrochronological method. It was possible to use three samples to create the average tree-ring curve which was dated by dendrochronology to year 1322 according to the Moravian standard chronology (morges2005).

When a dated curve overlaps the standard chronology by sixty rings, the critical value of Student's t-distribution with $0.1 \%$ level of significance is 3.46 (Šmelko and Wolf, 1977). The values of our t-tests are much higher

Table 3. The results of the dating of samples from the Bečva basin.

\begin{tabular}{llcccc}
\hline $\begin{array}{l}\text { Sam- } \\
\text { ple } \\
\text { no. }\end{array}$ & $\begin{array}{l}\text { Tree } \\
\text { species }\end{array}$ & $\begin{array}{c}\text { Num- } \\
\text { ber of } \\
\text { rings }\end{array}$ & $\begin{array}{c}\text { Outer- } \\
\text { most } \\
\text { ring }\end{array}$ & $\begin{array}{c}{ }^{14} \mathrm{C} \text { age } \\
\text { (yr BP) }\end{array}$ & $\begin{array}{c}\text { Cal. age range } \\
95.4 \% \text { conf. } \\
\text { intervals } \\
\text { (yr AD/BC) }\end{array}$ \\
\hline 1 & oak & 68 & $+2 k s$ & $1030 \pm 60$ & $885-1155 \mathrm{AD}$ \\
\hline 2 & oak & 172 & $+2 a k$ & $1230 \pm 50$ & $665-895 \mathrm{AD}$ \\
\hline 3 & oak & 67 & $+4 a k$ & $2600 \pm 110$ & $945-405 \mathrm{BC}$ \\
\hline 4 & oak & 46 & $+3 a k$ & $730 \pm 50$ & $1205-1320 \mathrm{AD}$ \\
\hline
\end{tabular}

Note: Radiocarbon dating conducted in Gliwice Radiocarbon Laboratory

Table 2. The results of the dating of samples from gravel pit Tovačov.

\begin{tabular}{|c|c|c|c|c|c|}
\hline Sample no. & Tree species & Number of rings & Outermost ring & $\begin{array}{c}{ }^{14} \mathrm{C} \text { age } \\
\text { (yr BP) }\end{array}$ & $\begin{array}{c}\text { Cal. age range } \\
95.4 \% \text { conf. intervals } \\
\text { (yr AD/BC) }\end{array}$ \\
\hline 1 & oak & 132 & $+2 a k$ & $3990 \pm 60$ & $2675-2295 \mathrm{BC}$ \\
\hline 2 & oak & 182 & $+2 a k$ & $3910 \pm 50$ & $2500-2275$ BC \\
\hline 3 & oak & 157 & $+11 \mathrm{ks}$ & $4000 \pm 50$ & $2670-2395$ BC \\
\hline 4 & oak & 116 & $+10 \mathrm{ks}$ & $3870 \pm 60$ & $2490-2190 \mathrm{BC}$ \\
\hline 5 & oak & 113 & $+1 \mathrm{ak}$ & $2150 \pm 45$ & $265-50 \mathrm{BC}$ \\
\hline 6 & oak & 35 & $+4 a k$ & $2070 \pm 45$ & $205 \mathrm{BC}-25 \mathrm{AD}$ \\
\hline 7 & oak & 54 & $+1 \mathrm{ks}$ & $2060 \pm 40$ & $195 \mathrm{BC}-25 \mathrm{AD}$ \\
\hline 8 & oak & 66 & $+1 \mathrm{ks}$ & $4010 \pm 85$ & $2780-2290 \mathrm{BC}$ \\
\hline 9 & oak & 95 & $+3 a k$ & $2757 \pm 84$ & 1129-789 BC \\
\hline 10 & oak & 105 & $+1 \mathrm{ks}$ & $1815 \pm 82$ & 48-404 AD \\
\hline 11 & oak & 57 & $+3 a k$ & $2053 \pm 83$ & $233 \mathrm{BC}-126 \mathrm{AD}$ \\
\hline 12 & oak & 127 & $+2 \mathrm{ks}$ & $3344 \pm 85$ & 1783-1446 BC \\
\hline 13 & oak & 88 & $+4 \mathrm{ks}$ & $1857 \pm 83$ & $3 \mathrm{BC}-352 \mathrm{AD}$ \\
\hline
\end{tabular}

Used abbreviations: ak - For the samples which do not retain underbark rings (ak) only the year after which the trees stopped growing can be determined; $k s$ - If heartwood and sapwood are retained (ks), the sample can be dated with the tolerance of several years (in the CR it is 5-21 rings). 
Table 4. The results of the dating of samples from gravel pit Osek nad Bečvou.

\begin{tabular}{lllllll}
\hline Sample no. & Tree species & Number of rings & Outermost ring & Initial year & Final year & Dendrochronological dating \\
\hline 1 & oak & 62 & $+2 a k$ & $919 A D$ & $981 \mathrm{AD}$ & after $983 \mathrm{AD}$ \\
\hline 2 & oak & 115 & $+3 a k$ & $900 \mathrm{AD}$ & $1015 \mathrm{AD}$ & after $1018 \mathrm{AD}$ \\
\hline 3 & oak & 54 & $+2 a k$ & $931 \mathrm{AD}$ & $985 \mathrm{AD}$ & after $987 \mathrm{AD}$ \\
\hline 4 & oak & 52 & $+1 a k$ & $936 \mathrm{AD}$ & $988 \mathrm{AD}$ & after $989 \mathrm{AD}$ \\
\hline
\end{tabular}

than 3.46 (Table 5), which shows high reliability of the dating. The correctness of the synchronization is also proved by the agreement of the standard chronology with the average tree-ring curve in most of the extreme values (Fig. 3). The other samples were dated independently, by means of either the Moravian or the south German standard chronologies, to the period between the $10^{\text {th }}$ and the $15^{\text {th }}$ centuries (Table 6).

\section{DISCUSSION AND CONCLUSION}

In the Czech Republic two kinds of oak are predominant - Quercus robur L. (Pedunculate Oak) and Quercus petraea (Matt.) Liebl. (Sessile Oak). Because the wood of these two kinds is not distinguishable by means of anatomical analysis, both kinds will be referred to by their species name - oak. Oak is a tree species which grows mainly in lowland floodplain forests. In the Czech Republic, it is to be found mainly in alluvial plains of large low-plain rivers (the Morava, the Vltava, the Labe). Subfossil trunks are remnants of floodplain forests. Because the river bed is in almost the same location, it is possible to find subfossil trunks in the river basins. Table 1 shows that within the research conducted in the Czech Republic before 2001 subfossil trunks were very often found near the Morava River and its main tributary, the Bečva River. For these reasons, these sites were selected and contacted when the research was being established. These are mainly unregulated reaches of rivers and gravel pits or sand pits.

In the area of the Morava, 99 trunks in total were found during the past two years, out of which 29 trunks were from the river basin and 70 came from gravel pits. Over $90 \%$ of them are oak samples, and exceptionally beech, maple, poplar or elm were found (Fig. 1). This may mean that there were mainly mixed forests but especially oak was preserved, which is a logical consequence of its high resistance. The number of rings in the samples ranges between 35 and 185 . Literature says that the number of rings is usually between 150 and 400 tree rings, which is related to the frequency of floods which make trees die (Becker, 1993). We can presume that most of

Table 5. The results of sample correlation with the standard chronology.

\begin{tabular}{llllll}
\hline A & B & C & D & E & F \\
\hline MORGES2005 & 4.88 & 5.25 & 61.60 & 112 & 1322 \\
\hline
\end{tabular}

A standard chronology

B T.test 1 (according to Baillie \& Pilcher)

C T.test 2 (according to Hollstein)

D curve parallelism in percents

E sample overlap with standard chronology in years F dating

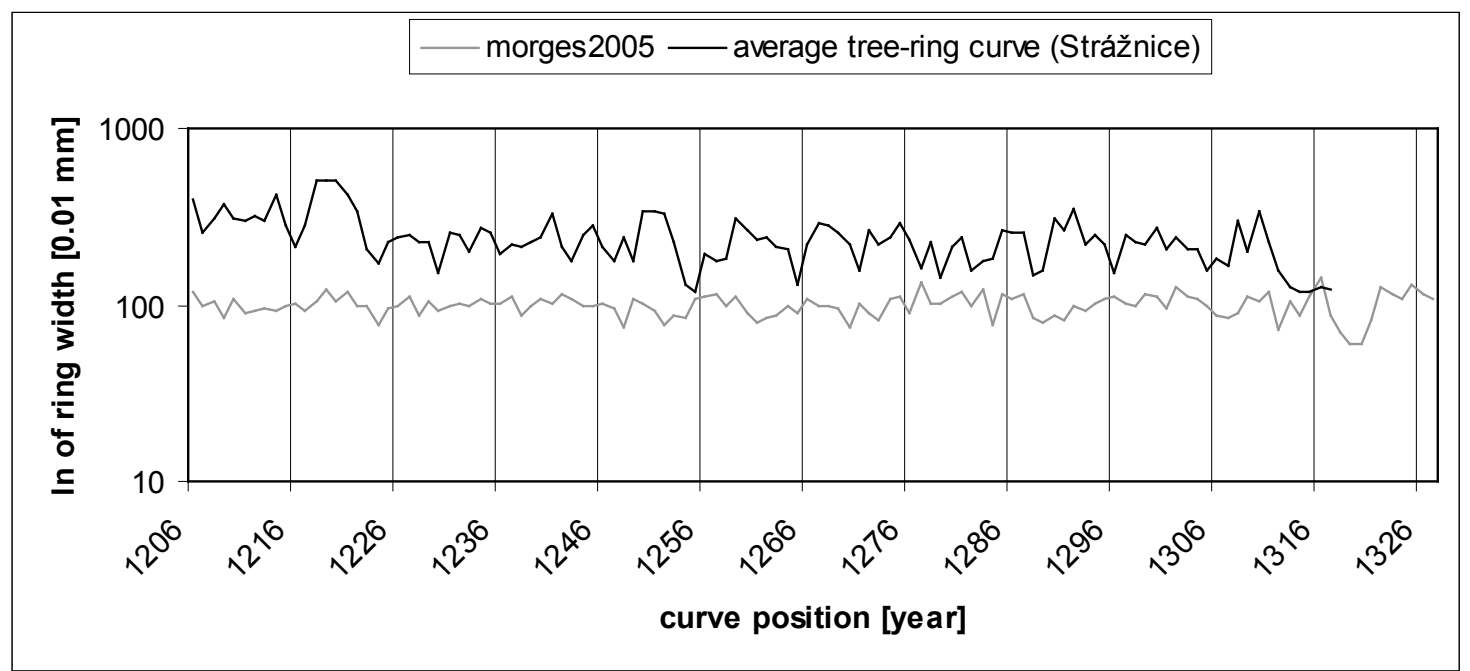

Fig. 3. Synchronization of the average tree-ring curve with the Moravian oak standard chronology MORGES2005. 
Table 6. The results of the dating of samples from the Morava River near Strážnice.

\begin{tabular}{|c|c|c|c|c|c|c|c|c|}
\hline Sample no. & Tree species & Number of rings & $\begin{array}{l}\text { Outermost } \\
\text { ring }\end{array}$ & $\begin{array}{l}\text { Initial } \\
\text { year }\end{array}$ & Final year & Dendrochronological dating & $\begin{array}{l}{ }^{14} \mathrm{C} \text { age } \\
\text { (yr BP) }\end{array}$ & $\begin{array}{c}\text { Cal. age range } \\
95.4 \% \text { conf. interval } \\
\text { (yr AD/BC) }\end{array}$ \\
\hline 1 & oak & 119 & $+2 a k$ & 1455 & 1574 & after $1576 \mathrm{AD}$ & $359 \pm 80$ & $1416-1668 \mathrm{AD}$ \\
\hline 2 & oak & 98 & $+2 a k$ & - & - & - & $758 \pm 81$ & $1148-1397 \mathrm{AD}$ \\
\hline 3 & elm & - & - & - & - & - & $310 \pm 80$ & $1436-1684 \mathrm{AD}$ \\
\hline 4 & oak & 57 & $+1 \mathrm{ks}$ & - & - & - & $307 \pm 80$ & $1436-1685 \mathrm{AD}$ \\
\hline 5 & - & - & - & - & - & - & $4717 \pm 87$ & $3664-3337 \mathrm{BC}$ \\
\hline 6 & oak & 152 & $+2 a k$ & 1356 & 1508 & after $1510 \mathrm{AD}$ & $576 \pm 80$ & $1274-1451 \mathrm{AD}$ \\
\hline 7 & oak & 90 & $+1 a k$ & 1232 & 1322 & after $1323 \mathrm{AD}$ & $734 \pm 81$ & $1153-1408$ AD \\
\hline 8 & oak & 98 & $+2 a k$ & 1210 & 1308 & after $1310 \mathrm{AD}$ & $701 \pm 81$ & $1175-1413 \mathrm{AD}$ \\
\hline 9 & oak & 57 & $+2 a k$ & 1226 & 1283 & after $1285 \mathrm{AD}$ & $858 \pm 81$ & $1026-1276$ AD \\
\hline 10 & oak & 161 & $+2 a k$ & 897 & 1058 & after $1060 \mathrm{AD}$ & $1053 \pm 81$ & $798-1160$ AD \\
\hline 11 & oak & 138 & $+7 a k$ & 1390 & 1528 & after $1535 \mathrm{AD}$ & $321 \pm 80$ & $1432-1682$ AD \\
\hline 12 & oak & 107 & $+1 a k$ & 1479 & 1586 & after $1587 \mathrm{AD}$ & $394 \pm 73$ & $1416-1647$ AD \\
\hline 13 & oak & 64 & $+3 a k$ & 1517 & 1581 & after $1584 \mathrm{AD}$ & $418 \pm 73$ & $1403-1645$ AD \\
\hline 14 & oak & 185 & $+1 a k$ & 1462 & 1647 & after $1648 \mathrm{AD}$ & $454 \pm 73$ & 1390-1636 AD \\
\hline
\end{tabular}

Note: Radiocarbon dating conducted in laboratory in Prague

the trunks found in the Morava River basin died due to more frequent floods or other mechanism of tree dying. The most probable reason for tree dying is the shifting of river banks in the meander during the year, which can be up to several meters.

As most samples could not be dated by the dendrochronological method, the radiocarbon method was used. Most dated trunks (13 in total) came from Tovačov (Table 2) and they were all dated by the radiocarbon method. Using the results, we can divide the samples into four periods. The first group consists of five samples from years 2780-2190 BC. The second group has six samples from 265 BC-404 AD. The remaining two samples were number 12 (1129-789 BC) and number 22 (1783-1446 BC). We can conclude that the conditions of this site were favourable for the growth of oak forests for more than four thousand years. The samples could not be dated by dendrochronological methods because their tree rings show a regular four-year cycle in which each fourth ring was significantly narrower than the previous three. The cycle was probably caused by the fact that the living trees were attacked by cockchafer (Melolontha, Linnaeus) (Christensen, 1987). This beetle is a typical defoliator of mainly broad-leaved tree species in entire Europe, especially in low lands. Cockchafer can have three- to fiveyear life cycle dependent on climatic conditions. Its attack causes a considerable reduction in diameter increment as soon as in the year of attack. The deformed treering curves cannot be dated by means of dendrochronology. Therefore, other samples could not be synchronized with samples dated by the radiocarbon method. The trend of the curves is so significantly affected by the attack that the results of other dated samples would be distorted. Moreover, these samples have to be excluded from the creation of the oak standard chronology of subfossil trunks.
A site with an abundant appearance of trunks is in Osek nad Bečvou. Besides the trunks found in the Bečva River, a lot of trunks were found during gravel extraction in the newly opened gravel pit. In total, 50 samples were taken here but it was not possible to use them to create the average tree-ring curve. Four samples from the gravel pit were dated by the German oak standard chronology to the period around $1000 \mathrm{AD}$. From the basin also four samples were dated - to the following periods: 945-405 $\mathrm{BC}$, 665-895 AD, 885-1155 AD, 1205-1320 AD (Tables 3 and 4).

The most southern site with frequent findings of trunks is a $12 \mathrm{~km}$ long reach of the Morava River flowing past Strážnice. In total, 16 samples were taken here, out of which 14 were dated. Three samples were used to create the average tree-ring curve and this was dated by the Moravian oak standard chronology MORGES 2005 to the period after 1322 (Fig. 2, Table 5). The other samples were dated by dendrochronological or radiocarbon methods to the period between the $8^{\text {th }}$ and the $17^{\text {th }}$ centuries (Table 6). In total, 259 samples from the Morava River basin have been processed with the purpose of standard chronology creation. In the years to follow we expect that further sampling in the above mentioned sites will be carried out and other sites with possible appearance of subfossil trunks will be searched for.

\section{ACKNOWLEDGEMENTS}

The paper was prepared within grant projects of the GAČR (Czech Science Foundation) no. 404/08/P367 "Compilation of the standard oak chronology of subfossil trunks for the purposes of dating of prehistoric wood", the GA AV ČR (The Grant Agency of the Academy of Sciences of the CR) no. IAAX00130801 "Relations between the climate, anthropogenic activities and landscape 
erosion recorded in nature archives of Strážnické Pomoraví (CR)”, VaV (R\&D) no. SP/2D1/93/07 „Czech Terra - adaptation of landscape carbon sinks in the context of global changes", GAČR (Czech Science Foundation) no. 205/08/0926 "Environmental significance of woody debris in river ecosystems", Research plan no. 6215648902 "Forest and timber - support for function-integrated forest management and utilization of timber as a renewable material".

\section{REFERENCES}

Baillie MGL, 1995. A slice through time: Dendrochronology and precision dating. $1^{\text {st }}$ issue. London: B.T. Batsford Ltd.: 176 pp. ISBN 0-7134-7654-0.

Becker B, 1982. Dendrochronologie und Paläoökologie subfossiler Baumstämme aus Flussablagerungen (Dendrochronology and Paleoecology of subfossil Tree Trunks from River Deposits). Mitteilungen der Kommission für Quartärforschung der Öesterreichischen Akademie der Wissenschaften 5: 120 pp (in German). ISBN 3700105452.

Becker B, 1993. An 11,000-year German oak and pine dendrochronology for radiocarbon calibration. Radiocarbon 35(1): 201-213. ISSN 0033-8222

Christensen K, 1987. Tree rings and insects: the influence of cockchafers on the development of growth rings in oak trees. Proceedings of the International Symposium an Ecoogical Aspects of Tree-Ring Analysis. Aspects of tree rings analysis, Palisades: 142-154.

Cook ER and Kairiukstis LA, 1990. Methods of Dendrochronology Applications in the Environmental Sciences. Dordrecht: Kluwer Academic Publisher and International Institute for Applied System Analysis: 408 pp. ISBN 0792305868

Dvorská J and Vít J, 2002. Dendrochronologické a radiometrické zpracování subfosilních kmenů z Mohelnice (Dendrochronological research and radiocarbon dating of subfossil trunks from Mohelnice, Northern Moravia). In: Anonymus, ed., 8. Kvartér 2002. Brno: 22-25 (in Czech).

Florek W, 1978. Pozycja czarnych dębów w osadach teras rzecznych i sposób ich fosylizacji w świetle badań z doliny Dolnego Bobru (Position of Black Oaks in River Terrace Sediments and How They Fossilize in the Light of Research from the Dolny Bobr Valley). Badania Fizjograficzne nad Polska Zachodnia Seria A 31: 79-92 (in Polish).

Govorčin S and Sinković T, 1995. Some physical and mechanical properties of the Bednja abonos. Drvna-Industrija 46(1): 9-14. ISSN 0012-6772

Leuschner HH, 1992. Subfossil Trees. In: Bartholin T, ed., Tree-Rings and Environment. Proceedings of the International Dendrochronological Symposium, Ystad, South Sweden. Lundqua Report 34: 193-197. ASIN B002WOEBOI

Leuschner HH, Delorme A and Höfle HC, 1986. Dendrochronological study of oak trunks found in bogs in northwest Germany. In Proceedings of the International Symposium on Ecological aspects of Tree-Ring Analysis. Tarrytown, New York, USA. pp. 298-318.

Kaennel M and Schweingruber F, 1995. Multilingual Glossary of
Dendrochronology: Terms and Definitions in English, German, French, Spanish, Italian, Portuguese and Russian. Birmensdorf, Swiss Federal Institute for Forest, Snow and Landscape Research. Berne, Stuttgart, Vienna: Paul Haupt Publisher: 467 pp. ISBN 3258-05259-X

Kalicki T and Krąpiec M, 1991. Subboreal black oaks identified from the Vistula alluvia at Grabie near Cracow (South Poland). Kwartalnik AGH-Geologia 17(1-2): 155-171.

Kalicki T and Krąpiec M, 1995. Problems of dating alluvium using buried subfossil tree trunks: lessons from the "black oaks" of the Pistula Halley, Central Europe. The Holocene 5(2): 243-250. ISSN 0959-6836. DOI 10.1177/095968369500500213.

Krąpiec M, 1996. Subfossil oak chronology (474 BC - AD 1529) from Southern Poland. In: Dean JS, Meko DM and Swetnam TW, Tree Rings, Environment and Humanity. Tucson, Arizona. Radicarbon: 813-819. ISSN 0033-8222

Krąpiec M, 2001. Holocene dendrochronological standards for subfossil oaks from the area of Southern Poland. Studia Quaternaria 18: $47-$ 63. ISSN 16415558

Máčka Z and Krejčí L, 2009. Interaction between river channel morphology and riparian vegetation - an example from the Lužnice River, South Bohemia, Czech Republic. In: Mentlík P and Hartvich F, eds., Geomorfological Proceedings 8, Abstract Proceedings, Department of Geography, University of West Bohemia in Pilsen, Institute of Rock Structure and Mechanics, The Academy of Sciences of the Czech Republic, v.v.i., The Czech Association of Geomorphologists, Brno: 38-39, ISBN: 978-80-7399-746-5

Pilcher JR, Baillie MGL, Schmidt B and Becker B, 1984. A 7,272 year tree-ring chronology for western Europe. Nature 312(5990): 150 52. ISSN: 0028-0836. DOI 10.1038/312150a0.

Poláček L, Škojec J and Tegel W, 2005. Jitka Vrbová-Dvorská und die Erforschung von subfossilen Baumstämmen aus tschechischen Flüssen (Jitka Vrbová-Dvorská and the Study of Subfossil Logs from Czech Rivers). In: Poláček, Lumír eds., Studien zum Burgwall von Mikulčice VI. Zvláštní tisk. Brno: Archeologický ústav AV ČR Brno: 23-49 (in German). ISBN 80-86023-31-1

Rybníček M, 2004. Dendrochronologická analýza krovu kostela Nanebevzetí Panny Marie a sv. Ondřeje ve Starém Hobzí (Dendrochronological analysis of the roof of the nanebevzetí Panny marie and Sv. Ondřeje churých in Staré Hobzí). Acta universitatis Agriculturae Et silviculturae Mendelianae Brunensis, LII(5): 155-168 (in Czech). ISSN 1211-8516

Rybníček M, Gryc V, Vavrčík H and Horáček P, 2007. Annual ring analysis of the root systém of Scots pine. Wood Research 52(3): 114.

Rybníček M, Koňas P and Kolář T, 2010. The Benefits of Tree-Ring Curves Detrending for Dating Archaeological Wood. Geochronometria 35(1): 85-90. DOI 10.2478/v10003-010-0004-6.

Spurk M, Friedrich M, Hofmann J, Remmele S, Frenzel B, Leuschner $\mathrm{HH}$ and Kromer B, 1998. Revisions and extensions of the hohenheim oak and pine chronologies - New evidence about the timing of the Younger Dryas/Preboreal-Transition, Radiocarbon 40(3): 110.

Šmelko Š and Wolf J, 1977. Štatistické metódy v lesnictve (Statistical Methods in Forestry). Príroda, 330 pp (in Slovak).

[RoS] Gliwice Radiocarbon Laboratory RoS. WEB site: $<$ http://www.carbon14.pl/c14lab/index.htm>. Accessed 2010 May 29. 